\title{
Kent Kimliği, Doğayla Temas ve Öznel İyi Oluṣ
}

\author{
Urban Identity, Contact with Nature, and Subjective Well-Being
}

\section{Gözde KIRAL UÇAR *}

$\ddot{O}_{z}$ : Çalışmalar, bireylerin yaşadıkları fiziksel çevreyle kurdukları ilişkilerin ve doğayla temaslarının öznel iyi oluşlarını güçlendirebileceğini göstermektedir. Bu çalışmada, Türkiye'nin batısında yer alan bir kentin sakinlerinden oluşan bir örneklemde kent kimliği, doğayla temas ve öznel iyi oluş arasındaki ilişkilerin incelenmesi amaçlanmıştır. Bireylerin yaşadıkları kentle kimliklenme ve doğayla temas etme düzeyleri ile öznel iyi oluşları arasında pozitif yönde bir ilişki olacağ 1 öngörülmüştür. Çalışmaya yaşları 17 ile 73 arasında değişen $(O r t=39.70 ; S S=$ 12.33; Kadın = 130) 213 kişi katılmıştır. Bulgular yaşın, kent kimliğinin karşılaştırma ve aidiyet boyutları üzerinde anlamlı bir etkisi olduğunu göstermiş ve en yüksek puanları 45 yaş üstü katılımcıların aldığı görülmüştür. Korelasyon bulgularına göre, kent kimliği; yaşam doyumu ve pozitif duygulanım ile pozitif yönde anlamlı korelasyonlar göstermiştir. Ayrıca, doğayla temas ve pozitif duygulanım arasında pozitif yönde anlamlı bir korelasyon bulunmuştur. Hiyerarşik regresyon analizi bulguları ise, demografik değişkenler ve sosyal istenirlik kontrol edildiğinde, aidiyetin yaşam doyumunu; doğayla temasın ise pozitif duygulanımı pozitif yönde yordadı̆̆ını göstermiştir.

Anahtar sözcükler: Yer Kimliği, Kent Kimliği, Doğayla Temas, Öznel İyi Oluş, Kent Sakinleri

Abstract: Studies have shown that individuals' relations with their own living environment and their contact with natural places can improve their well-being. In this study, it was aimed to test the associations between urban identity, contact with nature, and subjective well-being in a city located in the western part of Turkey. It was assumed that the stronger individuals' identity derived from the city they live in, the better well-being they should report. Moreover, higher levels of their contact with nature should be associated with better well-being. The sample consisted of 213 Turkish participants aged from 17 to 73 years $(M=39.70 ; S D=12.33$; Female =130). Results showed that age had an effect on external evaluation and attachment. The highest scores were obtained by the participants over 45 years. Urban identity was significantly correlated with life satisfaction and positive affect and contact with nature was significantly correlated with positive affect. The results of hierarchical multiple regression analyses indicated that after controlling demographics and social desirability, commitment positively predicted life satisfaction whereas contact with nature positively predicted positive affect.

Keywords: Place Identity, Urban Identity, Contact with Nature, Subjective Well-Being, City-Dwellers

\footnotetext{
* Dr. Öğr. Üyesi, Çanakkale Onsekiz Mart Üniversitesi, Fen-Edebiyat Fakültesi, Psikoloji Bölümü, Çanakkale. gozdekiral@gmail.com, gozdekiral@comu.edu.tr, https://orcid.org/0000-0001-5888-1101
} 
Giriş

Öznel iyi oluşa ilişkin erken dönem çalışmalar yalnızca negatif duygulanım ya da akı1 hastalıklarının bulunmadığı bir durumu tanımlarken, yeni çalışmalar kavramın kapsamını genişletmişlerdir (Diener 1984; Diener et al. 1999). İlgili alanyazında öne çıkan araştırmacılardan Diener'e (1984) göre öznel iyi oluş, görece yüksek düzeyde pozitif duygulanım ve düşük düzeyde negatif duygulanımın yanında bireyin kendi yaşamına ilişkin pozitif değerlendirmelerini de gerektirmektedir. Diğer bir ifadeyle, öznel iyi oluş üç önemli bileşenden oluşmaktadır. Bunlar, bireyin kendi yaşamını nasıl değerlendirdiği ve ne sıklıkla pozitif ve negatif duygulanım yaşadığıdır. Birey kendi yaşamına baktığında olumlu bir değerlendirme yapabiliyor, pozitif duyguları daha fazla ve negatif duyguları daha az deneyimliyorsa o bireyin, yüksek düzeyde bir öznel iyi oluşa sahip olduğu söylenebilir. Alanyazına göre öznel iyi oluş sosyo-demografik değişkenlerden kültüre uzanan çok geniş bir yelpazede sıralanan farklı etmenlerden etkilenmektedir (Diener 1984; Diener et al. 1999). Çevre psikolojisi yazını ise modern insanın psikolojik sağlığının onun yaşadığı yerle ve doğayla olan ilişkilenmelerinden de etkilendiğini öne sürmektedir (örn., Ulrich 1979). Bu çalışmada, kent insanının öznel iyi oluşunun yaşadığı kentle özdeşimi ve doğayla etkileşimi ile ne düzeyde ilişkili olduğunu incelemek amaçlanmıştır.

\section{Kent Kimliği ve Öznel İyi Oluş}

Bireyin yer (place) deneyimlerinin psikolojik bağlamı, ilgili alanyazında yer bağlılığı (place attachment; Hernandez et al. 2007), yer duygusu (sense of place; Jorgensen \& Stedman 2001) gibi farklı kavramlarla tanımlanmıştır. Yer kimliği de (place identity), kuşkusuz, öne çıkan kavramlardan biridir. Proshansky (1978) yer kimliğini "bireyin fiziksel çevreyle ilgili olarak kişisel kimliğini, bilinçli ya da bilinçli olmayan fikirlerin, inançların, tercihlerin, hislerin, değerlerin, amaçların ve bu fiziksel çevreye ilişkin davranışsal eğilimlerin ve yeteneklerin karmaşık bir örüntüsü yoluyla tanımlayan benliğin boyutları" (155) olarak ifade etmektedir. Araştırmacılara göre (Proshansky et al. 1983) yer kimliği toplumsal cinsiyet, toplumsal sınıf gibi bireyin öz-kimliğinin alt kategorilerinden bir tanesidir ve bireyin çevresiyle bilinçli ya da bilinçli olmayan etkileşimleri sonucunda gelişir; kimliğin diğer formlarının "ben kimim?" sorusuna sağladığ 1 tanımlara "neredeyim ve nereye aitim?" sorularına verilen yanıtlarla katkı sağlar. Yer kimliği, bireyin öz-kimliğini tanımlayan, koruyan, sürdüren fiziksel çevre bilişlerini temsil eder ve diğer bilişsel sistemler gibi bireylerin, fiziksel çevrelerini nasıl gördüklerini, yerler hakkında neler hissetiklerini ve düşündüklerini etkiler. Bu bağlamda, Proshansky ve arkadaşları (1983) yer kimliğinin birtakım işlevleri olduğunu ileri sürmektedir. Öncelikle, bireylere çevresel bir geçmiş sağlayarak gündelik yaşantılarında fiziksel dünyalarının şu andaki devamlılığ gelecekte de devam edeceği algısını oluşturur (recognition function). İkinci olarak, bireyler için bir anlam kaynağıdır; belirli fiziksel çevrelerde nelerin olması gerektiğine, kendisinin ve diğerlerinin nasıl davranması gerektiğine ilişkin çerçeveler sunar (meaning function). Bireylerin afektif ve estetik seçimlerinin tatmin olması bağlamında zevk ve tercihlerini yansıtan bilişleri içerir (expressive-requirement function). Bireyin yer kimliği ve o anki fiziksel çevre arasındaki uyuşmazlıkları bireydeki ilgili ve birbiriyle ilişkili bilişleri bu uyuşmazlığı azaltmak ya da ortadan kaldırmak için harekete geçirir (mediating change function). Son olarak, fiziksel çevrelerdeki tehdit ya da tehlikelere işaret edebilir ya da fiziksel ve/veya psikolojik iyiliğini tehdit eden tehlikelere karşı bireyin kendini koruma ve savunma tepkilerine ilişkin eğilimlerini temsil edebilirler (anxiety and defense function) (Proshansky et al. 1983). Başka bir deyişle, bireylerin yere ilişkin algı ve deneyimlerinin çeşitli işlevleri vardır ve bunlar bireylere çeşitli psikolojik faydalar sağlayabilirler.

Yer kimliğinin bireylerin psikolojik sağlıkla ilgili çıktılarıyla ilişkili olduğu araştırmacılar tarafından sıklıkla öne sürülmektedir. Örneğin, bazı araştırmacılar (örn., Brown \& Perkins 1992; Low \& Altman 1992) yer kimliğinin bireylere güvenlik duygusu, öngörülebilirlik ve 
kontrol, kendini ifade etme ve kimlik oluşturma gibi işlevler sağladığını ileri sürmektedir. Ayrıca yerle kimlik özdeşimi bireye "evde olma", kendi gibi hissetme, konforlu hissetme gibi duygular da yaşatır (örn. Cuba \& Hummon 1993). Bireylerin yer kimliklenmelerinin psikolojik sağlıklarına doğrudan etkisini ele alan çok fazla araştırma bulunmasa da (örn. Long et al. 2003, 20), mevcut araştırmaların bulguları bu varsayımı destekler niteliktedir. Örneğin, Long ve arkadaşları (2003), Baltimore' da yürüttükleri boylamsal bir çalışmada yer kimliğinin stres, sosyal destek, mahalledeki suç oranı, sosyo-demografik özellikler gibi değişkenler kontrol edildiğinde bile psikolojik sağlıkla ilişkili olduğunu gözlemlemiştir. Araştırmacılar, yaşadığ 1 yere ilişkin güçlü bir kimliklenme deneyimine sahip olmalarının, katılımcıların psikolojik sağlıklarını uzun vadede pozitif yönde yordadığını gözlemlemişlerdir. İngiltere'de iki kentte yürüttükleri nitel bir çalışmada yer kimliğinin psikolojik sağlık için anlamını inceleyen Bolam ve arkadaşları (2006), yaptıkları derinlemesine görüşmelerde yer kimliğinin psikolojik sağlıkla ilişkili üç boyutunun öne çıktığını gözlemlemişlerdir. Bu boyutlar yerin fiziki koşulları gibi maddi özellikleri, psikolojik ve toplumsal boyutlarıdır ve birbirinden ayrı konumlanmakla birlikte birbiriyle örtüşen özellikler de göstermektedir. Araştırmacılar bu çalışmada yer kimliğinin psikolojik sağlık için önemli bir unsur olduğunu ve katılımcıların yer kimliklenmelerinde gözlemlenen insan öznelliğinin psikolojik sağlık için önemli göstergeler içerdiğini ifade etmektedir. İsveç'te yürütülen bir çalışmada benzer biçimde araştırmacılar (Knez et al. 2018), yer kimliği ve öznel iyi oluş arasında pozitif bir ilişki gözlemlemiştir. Yerle güçlü özdeşim kuran katılımcılar yüksek düzeyde yaşam doyumu ve pozitif duygu bildirmişlerdir.

Bu çalışmada, bireylerin yaşadıkları yerle özdeşimi Lalli'nin (1992) kent kimliği bağlamında incelenmiştir. Lalli (1992), kent kimliği kavramını yer kimliğine benzer bir biçimde öz-kimliğin bir boyutu olarak ele almakla birlikte kent kimliğinin daha lokal bir içeriğe vurgu yapan, ayrıca, yer kimliğinin bilişsel formülasyonunun ötesine geçen bir kavram olduğunu öne sürmektedir. Araştırmacıya göre, yer kimliğine bu bilişsel yaklaşım onun toplumsal yanını gözden kaçırmaktadır. Toplumsal deneyimler belli mekanlarda gerçekleşir ve bu fiziksel çevreler davranış için bir çerçeve sağlar. Bireyin bir kentle öznel ilişkisi aile üyeleri, arkadaşlar, komşularla bağlar ya da farklı fiziksel aktiviteler aracılığıyla gerçekleşir. Başka bir deyişle, kent kimliği bireyin kentsel çevre ile karmaşı ilişkilerinin bir sonucudur ve kent kimliğinin toplumsal inşası önem taşımaktadır. Lalli (1992), kentlerin bireyin bu kişisel deneyimlerinin bir sembolü haline geleceğini ve bireye devamlılık duygusu sağlayacağını öne sürmektedir. Ayrıca, kimliğin gelişiminde ben ve öteki arasındaki ayrım sürecinde olduğu gibi, kendini belli bir kentin sakini olarak tanımlamak da bireyin, kendini o kentte yaşamayan diğerlerinden ayırmasına yarayacağını ve kent sakinleri ve diğerleri arasında algılanan bu ayrım yoluyla bireyin aidiyet geliştirebileceğini ifade etmektedir. Bu aidiyet, bireye kendini güvende ve rahat hissetme işlevi sağlayacaktır. Kentler de, ayrıca, "endüstriyel", "geleneksel”, "temiz" v.s. olmak gibi özelliklere sahiptir ve sakinleri tarafından kentlere de bir kimlik atfedilebildiğinden araştırmacıya göre, kentin bu algılanma biçimi yoluyla kent kimliği bireylerin olumlu benlik tanımlarına da hizmet edebilir. Başka bir deyişle, bireylerin kimliklendiği kenti diğer kentlerden ayıran özellikler bireylerin kendilerini diğerlerinden ayrı kılan özellikleri beslemeye hizmet edebilir (292-294).

\section{Doğayla Temas ve Öznel İyi Oluş}

Doğayla temasın psikolojik sağlık üzerindeki etkisini ele alan öne çıkan üç kuramsal yaklaşımın Biyofili Hipotezi, Dikkat Yenileme Teorisi ve Stres Azaltma Teorisi olduğu söylenebilir. Biyofili Hipotezi (Kellert \& Wilson 1993), insan atalarımızın doğal çevreyle olan bağının evrimsel olarak bize aktarıldığını ifade etmektedir. Bu hipoteze göre, her ne kadar modern insan yaşamı doğal çevreden uzaklaşsa da, bireyler doğal çevreyle etkileşime geçmeye ilişkin yoğun bir arzu duymaktadır. Dolayısıyla, doğayla temasın bireyler üzerinde olumlu sonuçları olacaktır.

Dikkat Yenileme Teorisi (Kaplan 1995) ise bilişsel süreçler üzerinde yoğunlaşır. Kurama 
göre, modern kentsel çevreler bireylerin bilişsel olarak tükenmelerine yol açarken doğal çevreler insanın evrimsel geçmişine uygun uyaranlarla dolu olduğundan dolayı yenileyici çevrelerdir ve gerek bilişsel gerekse duygusal açidan yenileyici deneyimler sunar.

Stres Azaltma Teorisi de (Ulrich 1979), benzer bir biçimde, insanın evrimsel tarihi uyarınca aşina olduğu doğal çevrelerle temasin bireylerde stresi azaltacağı ve yenilenme sağlayarak, örneğin, korku, kızgınlık gibi negatif duyguların azalması, pozitif duygulanımın artması, bilişsel performansın güçlenmesi gibi olumlu sonuçlar doğuracağını öne sürmektedir (Ulrich et al. 1991). Araştırmacılar, bu sonuçların, kentsel çevrelerden ziyade su kaynakları, yeşil alanlar gibi doğal çevrelerle temasta ortaya çıkacağını ifade etmektedir.

İlgili alanyazında, bu kuramsal perspektiflerin varsayımlarını destekleyen çok sayıda çalışma bulunmaktadır. Çalışmalar, sınırlı düzeyde temasın bile insanın psikolojik sağlığı üzerinde olumlu etkilere yol açtığını göstermektedir. Örneğin, Hartig ve arkadaşları (2003) yürüttükleri deneysel bir çalışmada, bir laboratuvar görevini yerine getirdikten sonra bir süreliğine ağaç manzaralı bir odaya alınan katılımcıların kan basınçlarındaki düşüşün; bir manzarası olmayan odaya alınanlarınkine oranla daha fazla olduğunu gözlemlemiştir. Yine aynı çalışmada, doğal bir çevrede yürüyüş yapan katılımcıların dikkat testinde gösterdikleri performans artarken kentsel alanda yürüyüş yapanlarda azalma görülmüştür. Doğal çevrede yürüyüş yapan katılımcıların, ayrıca, pozitif duygulanımlarında artış, kızgınlık duygusunda azalma görülürken kentsel alanda yürüyüş yapan katılımcılarda tersi bir durum gözlenmiştir. Bir başka deneysel çalışmada, Nisbet ve Zelenski (2011), bireylerin dışarıda, kendilerine yakın mesafedeki kentsel yeşil alanlarda yaptıkları yaklaşık 17 dakikalık yürüyüşlerden sonra; iç mekanda aynı sürede yapılan yürüyüşlere göre daha yüksek düzeyde pozitif duygulanım bildirdiklerini gözlemlemiștir. McMahan ve Estes (2015) toplamda 2356 katılımcıyla yürütülmüş 32 araştırmayı içeren bir meta analizde doğal çevrelerle etkileşimin katılımcıların duygusal iyi oluşlarını tutarlı bir biçimde etkilediğini rapor etmiştir. Şöyle ki, doğal çevrelerle temasla birlikte pozitif duygulanım artmaktayken olumsuz duygulanımda ise, pozitif duygulanımdaki artış kadar güçlü bir değişim olmasa da azalma görülmektedir.

Araştırmacılar (örn., Korpela et al. 2001), doğal alanların günlük rutinden ve gündelik endişelerden uzaklaşmayı sağladığını dinlendirici ve sakinleştirici olduğunu ifade etmektedir. $\mathrm{Bu}$ durumda doğal çevreler bireylerin psikolojik sağlıklarını güçlendirmede önemli bir kaynak gibi görünmektedir.

\section{Araştırmanın Amacı ve Hipotezler}

$\mathrm{Bu}$ araştırmada, kent kimliği, doğayla temas ve öznel iyi oluş ilişkilerinin incelenmesi amaçlanmıştır. Ayrıca, farklı yaş grupları arasında kent kimliği bakımından bir fark olup olmadığ incelenmiştir. Bu amaçlar doğrultusunda araştırmanın hipotezleri aşağıdaki gibi ifade edilmiştir.

Alanyazında kent kimliğinin yaştan etkilendiği, ileriki yaşlarda kent kimliğinin daha güçlü olduğu yönündeki bulgulara (örn. Belanche et al. 2017) dayanarak yaşın kent kimliği üzerinde anlamlı bir etkisinin olması öngörülmektedir.

$\mathrm{H}_{1}$. İleriki yaşlardaki katılımcıların kent kimliği daha güçlüdür.

Alanyazında, yer kimliğinin öznel iyi oluşla pozitif yönde ilişkili olduğuna işaret eden çalışmalar (örn. Knez et al. 2018) bulunmaktadır. Buradan hareketle, kent kimliği ve öznel iyi oluş arasında pozitif yönde anlamlı bir ilişki beklenmektedir.

$\mathrm{H}_{2}$. Kent kimliğinin aidiyet, karşılaştırma ve gelecek boyutları öznel iyi oluşun pozitif duygulanım ve yaşam doyumu boyutlarını pozitif yönde; negatif duygulanımı ise negatif yönde yordar.

Doğayla temas ve öznel iyi oluş arasındaki pozitif yöndeki ilişki alanyazında tutarlı bir biçimde ortaya konmuştur (örn. McMahan \& Estes 2015). Bu çalışmada da, doğayla temas ile 
öznel iyi oluş arasında pozitif yönde anlamlı bir ilişki olması öngörülmektedir.

$\mathrm{H}_{3}$. Doğayla temas öznel iyi oluşun pozitif duygulanım ve yaşam doyumu boyutlarını pozitif yönde, negatif duygulanımı ise negatif yönde yordar.

\section{Yöntem}

\section{Katılımcılar ve İşlem}

Araştırmaya yaşları 17 ile $73(M=39.70 ; S D=12.33)$ arasında değişen 213 gönüllü katılmıştır. Katılımcıların 130'u (\%61) kadın, 83’ü (\%39) erkektir. Katılımcıların 11'i (\%5.2) ilkokul, 6's1 (\%2.8) ortaokul, 46's1 (\%21.6) lise, 22'si (\%10.3) önlisans, 101'i (\%47.4) lisans, 26’s1 (\%12.2) lisansüstü mezunudur. Katılımcıların 119'u (\%55.9) kendini orta halli olarak tanımlamış ve 128'i (\%60) yaşamının büyük bir kısmını şehirde geçirdiğini ifade etmiştir.

Çalışmanın verileri Çanakkale kentinde, Kasım-Aralık 2018 tarihleri arasında kalem-kâğıt formunda toplanmıştır. Çalışmanın uygulaması için üniversiteden etik kurul onayı alınmıştır. Katılımcıların her birine bilgilendirilmiş onam formu imzalatılmış, uygulamanın gönüllülük esasına dayandığı, istedikleri zaman uygulamayı yarıda bırakabilecekleri ve uygulama süresi konusunda bilgi verilmiştir. Uygulama süresi yaklaşık 15 dakikadır.

\section{Veri toplama araçları}

Demografik bilgi formunda, katılımcıların cinsiyet, eğitim, meslek, yaş, çalışma durumu ve ekonomik düzey gibi demografik özelliklerini belirlemeye yönelik sorular yer almaktadır.

Kent Kimliği Ölçeği, Lalli (1992) tarafından geliştirilen ve 20 maddeden oluşan bir ölçektir. Ölçek, bu çalışmada 1 "Hiç katılmıyorum" ve 6 "Tamamen katılıyorum" arasında değişen 6 dereceli Likert tipi bir ölçek olarak kullanılmıştır. Ölçeğin, geçerlik ve güvenirlik çalışması Göregenli (2005) tarafindan gerçekleştirilmiş ve tek boyutlu bir ölçek olarak kent kimliğini ölçebileceği gibi "Aidiyet", "Gelecek" ve "Karşılaştırma" alt ölçeklerinin her birinin ayrı ayrı da kullanılabileceği ifade edilmiştir (Akt. Karakuş 2014).

"Aidiyet Alt Ölçeği” bireyin yaşadığı kente aidiyet düzeyiyle ilişkilidir. Bu alt ölçekten yükssek puan almak bireyin yaşadığ gelmektedir (örnek maddeler: "Çanakkale'de kendimi evimdeymiş gibi hissediyorum"; "Başka bir yerde yaşayabileceğimi düşünmüyorum; eğer yaşarsam kendimle ilgili pek çok şeyden vazgeçmek zorunda kalacağım”). "Gelecek Alt Ölçeği” bireyin yaşadığı kentte gelecekte de yaşamaya istekli olması ile ilgilidir (örnek maddeler: "Kişisel geleceğimde Çanakkale'nin çok önemli bir yeri var"; "Çanakkale'nin geleceğini merak ediyorum, nasıl bir yer olacağını görmek istiyorum"). "Karşılaştırma Alt Ölçeği" ise bireyin yaşadığı kenti diğer kentlerle karşılaştırdığında yaptığı değerlendirmelerle ilgilidir (örnek maddeler: "Diğer illerle kıyaslandığında Çanakkale pek çok avantaja sahiptir"; "Çanakkale, diğer illerde yaşayanlar tarafından "yaşanılacak" bir kent olarak görülür").

$\mathrm{Bu}$ çalışmada, ölçeğin aidiyet, gelecek ve karşılaştırma alt ölçeklerinin Cronbach Alfa değerleri sırasıyla; $.95, .92$ ve .82 olarak bulunmuştur. Tüm ölçeğin Cronbach Alfa değeri ise Karakuş'un (2014) çalışmasında olduğu gibi, .95'tir.

Yaşam Doyumu Ölçeği, Diener ve arkadaşları (1985) tarafindan geliştirilmiş bir ölçektir ve bu çalışmada 1 "Hiç katılmıyorum" ve 6 "Tamamen katılıyorum" arasında değişen 6 dereceli Likert tipi bir ölçek olarak kullanılmıştır. Ölçekten alınan yüksek puanlar bireylerin yaşamlarından hoşnut olduklarını göstermektedir. Ölçek, İmamoğlu (2004) tarafından Türkçeleştirilmiş olup Cronbach Alfa değeri .88 olarak bulunmuştur (örnek maddeler: "Hayatımdan memnunum"; "Birçok bakımdan hayatım idealime yakın"). Bu çalışmada, ölçeğin Cronbach Alfa değeri .82 olarak bulunmuştur.

Pozitif ve Negatif Duygu Ölçeği, Watson ve arkadaşları (1988) tarafından geliştirilmiş, geçerlik ve güvenirlik çalışması ise Gençöz (2000) tarafından gerçekleştirilmiştir. Ölçek "Çok 
az veya hiç" ile "Çok fazla" arasında değişen 5 dereceli Likert tipi bir ölçektir. Pozitif Duygu Ölçeği; ilgili, güçlü, hevesli, ilhamlı gibi sıfatlar içerirken, Negatif Duygu Ölçeği ise mutsuz, suçlu, ürkmüş, düşmanca gibi sıfatlar içermektedir. Gençöz (2000) Pozitif Duygu Ölçeği'nin Cronbach Alfa değerini .83, Negatif Duygu Ölçeği'nin Cronbach Alfa değerini ise .86 olarak bulmuştur. Bu çalışmada ise Pozitif Duygu Ölçeği'nin Cronbach Alfa değeri .82; Negatif Duygu Ölçeği'nin Cronbach Alfa değeri .80 olarak bulunmuştur.

Doğayla Temas Ölçeği, Herzog ve Strevey'den (2008) alınmıştır. Ölçek maddeleri araştırmacı tarafından Türkçeleştirilmiş ve alanında uzman bir araştırmacı tarafından kontrol edilmiştir. Ölçek "Hiçbir zaman" ile "Çok sık" arasında değişen 5 dereceli Likert tipi bir ölçektir. Ölçeğin Türkçe formunun psikometrik özelliklerini değerlendirmek için geçerlik-güvenirlik analizi gerçekleştirilmiştir. Geçerlik analizi için doğrulayıcı faktör analizi uygulanmıştır. Orijinal ölçek tek faktörden oluştuğu için birinci düzey (first-order) faktör analizi yapılmıştır. Sonuçlara göre ölçeğin uyum indeksleri şu şekildedir, $\chi^{2}(27, N=213)=79.501, p<.001$, $\left(\chi^{2} / \mathrm{df}\right)=2.94$, GFI $=.92$, RMSEA $=.10$, SRMR $=.05$. Model uyum indeksini iyileştirmek amacıyla yapılacak değişiklikler için değiştirme göstergeleri (modification indices) temel alınmıştır. Buna göre, bazı maddelerin hata kavramları arasında (1. ve 3. maddeler, 7. ve 9. maddeler, 8. ve 9. maddeler) korelasyon parametrelerinin çizilmesinin model uyumunu artıracağ 1 görülmüştür. Bu korelasyonların ilgili boyutun maddeleri arasında olması nedeniyle hata kavramlarının ilişkisine izin verilmiştir. Çünkü hata kavramları arasındaki korelasyonların ölçme hatasından kaynaklandığı düşünülmektedir (bkz. Byren, 2010). Bu işlemden sonra model uyumu görece artmıştır. Sonuç olarak, elde edilen uyum iyiliği indeksleri ölçeğin orijinal formundaki tek faktörlü yapıya uyduğunu göstermektedir $\left(\chi^{2}(24, \mathrm{~N}=213)=42.613, p<.011\right.$, $\left.\left(\chi^{2} / \mathrm{df}\right)=1.78, \mathrm{GFI}=.96, \mathrm{RMSEA}=.06, \mathrm{SRMR}=.03\right)$.

Ölçeğin güvenirlik düzeyini değerlendirmek amacıyla gerçekleştirilen analiz sonucunda Cronbach Alfa değeri .90 olarak bulunmuştur.

Tablo 1. Doğayla Temas Ölçeği'nin Faktör Yükleri, Ortalama ve Standart Sapma Değerleri $(N=213)$

\begin{tabular}{llcc}
\hline Maddeler & Ort & SS & Faktör Yükü \\
\hline 1 Doğanın tadını çıkarmak & 3.70 & 0.93 & .77 \\
2 Sincapları, kuşları ya da diğer hayvanları seyretmek & 3.33 & 1.04 & .79 \\
3 Doğal bir ortamda yürüyüşe çıkmak & 3.58 & 0.95 & .73 \\
4 Gölgelik bir yerde dinlenmek & 3.53 & 0.90 & .68 \\
5 Bir parka gitmek & 3.51 & 0.91 & .73 \\
6 Açık havada (dışarıda) piknik yapmak & 3.41 & 0.95 & .75 \\
7 Bahçe işleriyle uğraşmak & 2.79 & 1.15 & .66 \\
8 Açık havada (dışarıda) vakit geçirmek & 3.92 & 0.90 & .63 \\
9 Kamp yapmak & 2.39 & 1.26 & .68 \\
\hline
\end{tabular}

Sosyal İstenirlik Ölçeği, Kemper ve arkadaşları (2012) tarafından geliştirilen ölçeğin 6 soruluk kısa versiyonudur. Ölçek, Kiral-Ucar ve arkadaşları (2016) tarafindan Türkçeleştirilmiştir. Ölçeğin 3 maddesi olumsuz niteliklerin ( $\alpha=.62$; örnek madde: "Bir kimseden çıkarım içim faydalandığım olmuştur”), diğer 3 maddesi ise olumlu özelliklerin abartılmasına ilişkindir ( $\alpha=$ .65; örnek madde: "Stresli olduğumda bile başkalarına arkadaşça ve nazik davranmaya özen gösteririm"). Ölçek, bu çalışmada 1 "Hiç katılmıyorum" ve 6 "Tamamen katılıyorum" arasında değişen 6 dereceli Likert tipi bir ölçek olarak kullanılmıştır.

\section{Bulgular}

$\mathrm{Bu}$ kısımda analiz bulgularına yer verilecektir. Verilerin analizinde değişkenler arasındaki ilişkileri değerlendirmek amacıyla Pearson korelasyon analizi yapılmıştır. Daha sonrasında; yaş, 
cinsiyet, eğitim düzeyi, ekonomik düzey ve sosyal istenirlik gibi değişkenler kontrol edildikten sonra, kent kimliğinin alt ölçekleri ile doğayla temas değişkenlerinin öznel iyi oluşa ilişkin değişkenleri ne ölçüde yordadığını belirlemek amacıyla hiyerarşik çoklu regresyon analizleri gerçekleştirilmiştir. Her analizde, ilk aşamaya kontrol değişkenleri dahil edildikten sonra ikinci aşamada kriter değişkenle korelasyon gösteren değişkenler analize dahil edilmiştir. Ayrıca Kent Kimliği Ölçeği'nin alt boyutlarından alınan puanlar bakımından yaş grupları arasında bir fark olup olmadığını saptamak amacıyla çok yönlü varyans analizi yapılmıştır.

\section{Korelasyon Analizi Bulguları}

Çalışmada yer alan değişkenler arasındaki ilişkileri belirlemek için yapılan korelasyon analizi bulguları Tablo 2'de gösterilmiştir.

Tablo 2'deki korelasyon değerlerine göre, kent kimliği, yaşam doyumu ve pozitif duygulanım arasında pozitif yönde anlamlı korelasyonlar olduğu görülmektedir. Bununla birlikte, doğayla temas ve pozitif duygulanım arasında pozitif yönde anlamlı bir korelasyon olduğu da görülmektedir. Diğer bir deyişle, yaşam doyumu ve pozitif duygulanımın kent kimliği düzeyiyle birlikte arttığı belirlenmiştir. Pozitif duygulanımın, ayrıca, doğayla temas düzeyiyle birlikte arttığı görülmektedir.

\section{MANOVA Analizi Bulguları}

Kent Kimliği Ölçeği'nin aidiyet, gelecek ve karşılaştırma boyutlarından alınan puanlar bak1mından yaş grupları arasında bir fark olup olmadığını saptamak amacıyla yapılan çok yönlü varyans analizini gerçekleştirmeden önce çalışmanın örneklemi, yaş dağılımı göz önünde bulundurularak, $17-30$ arası $(n=50), 30-45$ arası $(n=101)$ ve 45-73 arası $(n=61)$ olmak üzere üç farklı yaş grubuna ayrılmıştır. MANOVA bulguları yaşın etkisinin anlamlı olduğuna işaret etmektedir, Wilks' $\Lambda=.92, F(6,414)=2.72, p=.013, \eta 2=.04$. Yaşın anlamlı etkisi, aidiyet $F(2,209)=5.06, p=.01, \eta 2=.05$ ve karşılaştırma $F(2,209)=3.81, p=.02, \eta 2=.04$ boyutları için görülürken; gelecek $F(2,209)=2.25, p=.11, \eta 2=.02$ boyutu için görülmemiştir. Aidiyet boyutundan, 45-73 yaş arası katılımcıların $(O r t=5.01 ; S S=0.98), 30-45$ yaş arası $(O r t=4.38$; $S S=1.40)$ ve $17-30$ yaş arası $(O r t=4.66 ; S S=1.08)$ katılımcılara oranla en yüksek puanı aldıkları görülmüştür. Karşılaştırma boyutundan da benzer bir biçimde, 45-73 yaş arası katılımciların $(O r t=5.34 ; S S=0.70), 30-45$ yaş arası $(O r t=4.96 ; S S=0.96)$ ve $17-30$ yaş arası $(O r t=5.10 ; S S=0.76)$ katılımcılara oranla en yüksek puanı aldıkları görülmüştür. Gelecek boyutundan da, fark anlamlı değilse de, 45-73 yaş arası katılımcıların $(O r t=5.02 ; S S=1.04)$, $30-45$ yaş arası $(O r t=4.63 ; S S=1.29)$ ve $17-30$ yaş arası $(O r t=4.63 ; S S=1.23)$ katılımcılara oranla en yüksek puanı aldıkları söylenebilir.

\section{Regresyon Analizi Bulguları}

Hiyerarşik çoklu regresyon analizlerinden ilkine bakıldığında değişkenlerin yaşam doyumundaki varyansın toplamda \%23'ünü açıkladığı görülmektedir. Bu varyansın \%18'i katılımc1ların cinsiyeti $(\beta=0.13 ; p<.05)$, ekonomik düzeyleri $(\beta=0.38 ; p<.001)$ ve olumlu niteliklerin abartılmasını ifade eden sosyal istenirliğin ikinci alt boyutu $(\beta=0.15 ; p<.05)$ ile açıklanmaktadır. $\mathrm{Bu}$ değişkenler kontrol edildikten sonra, katılımcıların yaşadıkları şehirde gelecekte yaşamayı düşünüyor olmaları $(\beta=0.23 ; p<.05)$ ise yaşam doyumu varyansının $\% 5$ 'ini açıklamaktadır.

İkinci analizde değişkenler pozitif duygulanımdaki varyansın toplamda \%20'sini açılamaktadır. $\mathrm{Bu}$ varyansın $\% 11$ 'inin katılımcıların yaş $(\beta=-0.21 ; p<.01)$, cinsiyet $(\beta=0.17$; $p<.05)$ ve olumlu niteliklerin abartılmasını ifade eden sosyal istenirliğin ikinci alt boyutu $(\beta=$ $0.21 ; p<.01)$ ile açıklandığ görülmektedir. Katılımcıların demografik özellikleri ve sosyal istenirlik eğilimleri kontrol edildiğinde, doğayla temasin $(\beta=0.24 ; p<.001)$ pozitif duygulanıma tek başına \%9'luk bir katkı sağladığı görülmektedir. Doğayla temas eden katılımcıların daha pozitif duygular rapor ettikleri söylenebilir. Öte yandan, negatif duygulanımdaki 
varyansın toplamda $\% 16$ 'sının eğitim düzeyi $(\beta=-0.23 ; p<.001)$, olumsuz niteliklerin abartılmasını ifade eden sosyal istenirliğin birinci alt boyutu $(\beta=0.17 ; p<.05)$ ve olumlu niteliklerin abartılmasını ifade eden sosyal istenirliğin ikinci alt boyutu $(\beta=-0.16 ; p<.05)$ tarafından açıklandığı ve katılımcıların demografik özellikleri ve sosyal istenirlik eğilimleri kontrol edildiğinde negatif duygulanımı açıklamada hiçbir yordayıcı değişkenin katkı sağlamadığ1 görülmektedir.

\section{Tartışma}

Bu çalışmada, kent insanının öznel iyi oluş düzeyini belirleyen bazı sosyal psikolojik değişkenlerin incelenmesi amaçlanmıştır. Bu amaç doğrultusunda, bireylerin kent kimliği ve doğayla temas düzeylerinin öznel iyi oluşlarıyla ilişkisi ele alınmıştır. Ayrıca, bireylerin yaşadığı kentle kimliklenme süreçlerinde farklı yaş grupları arasında bir fark olup olmadığı incelenmiştir.

Araştırmanın hipotezleri genel olarak desteklenmiştir. Kent kimliği bakımından yaş grupları arasında bir fark olduğu gözlenmiştir $\left(\mathrm{H}_{1}\right)$. Çalışmanın örneklemi, yaş dağılımı göz önünde bulundurularak 17-30 arası, 30-45 arası ve 45-73 arası olmak üzere üç farklı gruba ayrılmıştır. Katılımcıların kent kimliğinin aidiyet, gelecek ve karşılaştırma alt boyutları bakımından yaşa göre farklılaşıp farklılaşmadığına bakıldığında 45 yaş üstü katılımcıların aidiyet ve karşılaştırma alt boyutlarından en yüksek puanı aldığı görülmüştür. 45 yaş üstü katılımcılar kenti daha yükssek bir oranda memleketleri ya da başka bir ifadeyle evleri olarak görmekte ve kente aidiyetlerini kimliklerinin daha önemli bir parçası olarak değerlendirmektedirler. Bu bulgular, ileriki yaşlarda kent kimliğinin daha güçlü olduğu yönündeki bulguları destekler niteliktedir (örn., Belanche et al. 2017). Araştırmanın amaçları arasında yer almasa da bazı demografik değişkenlerin öznel iyi oluşu yordadığı görülmektedir. Örneğin, cinsiyet hem yaşam doyumunu hem de pozitif duygulanımı yordamıştır. Erkek olmanın yaşamını daha olumlu yönde değerlendirme ve daha sıklıkla pozitif duygulanım yaşamakla ilişkili olduğuna işaret eden bu bulgu, alanyazınla tutarl11ık göstermektir (örn., Tesch-Römer, Motel-Klingebiel \& Tomasik 2008).

Araştırmadan elde edilen bir diğer bulgu, hem toplamda kent kimliğinin hem de kent kimliğinin aidiyet, gelecek ve karşılaştırma alt boyutlarının yaşam doyumu ve pozitif duygulanım ile pozitif yönde ilişkili olduğudur. Karşılaştırma alt boyutu ile negatif duygulanım arasında ise negatif yönde bir ilişki olduğu görülmektedir. Bir başka deyişle, katılımcıların kent kimliği güçlendikçe yaşamlarından memnuniyet duyma ve pozitif duygulanım yaşama olasılıklarının arttığı söylenebilir. Kent kimliğinin tek tek alt boyutlarına bakıldığında katılımcıların yaşadıkları kente aidiyet geliştirme, gelecekte de şu anda yaşadıkları kentte yaşamayı düşünme ve yaşadıkları kenti başka kentlerle karşılaştırdıklarında olumlu sonuçlara varma düzeyleri yükseldikçe katılımcıların yaşamlarından memnuniyet duyma ve pozitif duygulanım yaşama düzeylerinde de artma eğilimi gözlenmektedir. Ayrıca, yaşadıkları kenti başka kentlerle karşılaştırdıklarında olumlu sonuçlara varma düzeyleri yükseldikçe negatif duygulanım yaşama olasılıkları da azalmaktadır. Bu bulgular, yaşadığı yere ilişkin güçlü kimliklenme deneyimi yaşamanın bireylere sağladığ 1 birtakım yararlar olduğunu ileri süren araştırmacıların (Proshansky et al. 1983; Lalli 1992) görüşlerini destekler niteliktedir $\left(\mathrm{H}_{2}\right)$. İleri analizlere bakıldığında ise, kent kimliğinin yalnızca gelecek alt boyutunun öznel iyi oluşun yalnızca yaşam doyumu alt boyutunu yordadığı görülmektedir. Diğer bir deyişle, gelecekte de şu anda yaşadıkları kentte yaşamayı düşünen katılımcılar yaşam koşullarından ve genel olarak yaşamlarından memnuniyet duymaktadır. Yerleşim mobilitesinin bireylerin yaşadıkları yeri değiştirmesi ya da değiştirme niyetleriyle ölçülebileceğini (örn., Van Vugt et al. 2003, 327), yerleşim mobilitesinin yerleşim yeri memnuniyetinin önemli bir bileşeni olduğunu (örn., Bonnes et al. 2012) ve yerleşim yeri memnuniyeti ve yaşam doyumu arasında pozitif bir ilişki olduğunu (örn., Fernández-Portero et al. 2017) ileri süren araştırmalar dikkate alındığında bu çalışmanın bulgularının ilgili alanyazınla tutarlılık gösterdiği söylenebilir. 
Tablo 2. Korelasyon Bulguları ile Ortalama ve Standart Sapma Değerleri

$\begin{array}{lllllllllllll}(1) & (2) & (3) & (4) & (5) & (6) & \text { (7) } & \text { (8) } & \text { (9) } & \text { (10) } & \text { (11) } & \text { (12) } & \text { (13) }\end{array}$

\begin{tabular}{|c|c|c|c|c|c|c|c|c|c|c|c|c|c|c|}
\hline (1) Yaş & 1 & & & & & & & & & & & & & \\
\hline (2) Cinsiyet & .04 & 1 & & & & & & & & & & & & \\
\hline (3) Eğitim Düzeyi & $-.14 *$ & $-.17 *$ & 1 & & & & & & & & & & & \\
\hline (4) Ekonomik Düzey & .09 & -.11 & $.16^{*}$ & 1 & & & & & & & & & & \\
\hline (5) Aidiyet & $.17^{*}$ & -.08 & $-.17 *$ & .06 & 1 & & & & & & & & & \\
\hline (6) Gelecek & $.17^{*}$ & -.04 & -.08 & .04 & $.80^{* *}$ & 1 & & & & & & & & \\
\hline (7) Karşılaştırma & $.14^{*}$ & $-.18 * *$ & .09 & .13 & $.41^{* *}$ & $.44 * *$ & 1 & & & & & & & \\
\hline (8) Kent Kimliği & $.19^{* *}$ & -.09 & -.12 & .08 & $.97 * *$ & $.90 * *$ & $.57 * *$ & 1 & & & & & & \\
\hline (9) Doğayla Temas & -.01 & $.14^{*}$ & -.02 & $.14^{*}$ & $.19^{* *}$ & $.14^{*}$ & .07 & $.18^{* *}$ & 1 & & & & & \\
\hline (10) Yaşam Doyumu & .07 & .08 & .08 & $.38 * *$ & $.16^{*}$ & $.23^{* *}$ & $.20 * *$ & $.21 * *$ & .12 & 1 & & & & \\
\hline (11) Pozitif Duygu & -.11 & .13 & -.04 & .08 & $.15^{*}$ & $.19 * *$ & $.16^{*}$ & $.18^{* *}$ & $.30 * *$ & $.29 * *$ & 1 & & & \\
\hline (12) Negatif Duygu & -.06 & .11 & $-.26^{* *}$ & $-.18^{* *}$ & -.06 & -.08 & $-.14 *$ & -.09 & .01 & $-.21 * *$ & -.06 & 1 & & \\
\hline (13) Sosyal İstenirlik_Negatif & $-.33 * *$ & .13 & .02 & -.11 & -.10 & $-.15^{*}$ & $-.18 * *$ & $-.14^{*}$ & .07 & -.01 & -.11 & $.23 * *$ & 1 & \\
\hline (14) Sosyal İstenirlik_Pozitif & $.19 * *$ & -.04 & .02 & .04 & $.26^{* *}$ & $.28 * *$ & .09 & $.27 * *$ & $.14^{*}$ & $.14^{*}$ & $.21 * *$ & $-.23 * *$ & $-.32 * *$ & 1 \\
\hline Ort & 39.70 & .39 & 4.29 & 4.23 & 4.63 & 4.73 & 5.10 & 4.75 & 3.35 & 3.80 & 3.55 & 2.14 & 2.12 & 4.74 \\
\hline$S S$ & 12.34 & 0.49 & 1.30 & 0.76 & 1.24 & 1.22 & 0.85 & 1.02 & 0.75 & 0.95 & 0.62 & 0.62 & 1.00 & 0.79 \\
\hline
\end{tabular}

Not. Cinsiyet, $\operatorname{Kad} ı n=0 ;$ Erkek $=1 ; * p<.05 ; * * p<.01$ 
Doğayla temas yalnızca pozitif duygulanım ile pozitif yönde anlamlı bir ilişki göstermektedir. İleri analizlere bakıldığında da doğayla temasın pozitif duygulanımı yordadığı görülmektedir $\left(\mathrm{H}_{3}\right)$. Bu bulgu, doğada zaman geçirmenin ve aktivitelere katılmanın pozitif duygulanımla ilişkili olduğunun gösteren araştırmalarla (örn., Nisbet \& Zelenski 2011) ve doğal çevrelerle temasın öznel iyi oluşun diğer boyutlarından ziyade pozitif duygulanımla ilişkili olduğunu gösteren araştırmalarla (örn., McMahan \& Estes 2015) tutarlılık göstermektedir.

\section{Sonuçlar ve Öneriler}

Bu çalışma, kent kimliği, doğayla temas ve öznel iyi oluş arasındaki ilişkilerin anlaşılmasına yönelik hem Türkçe hem de uluslararası alanyazına katkı sunmaktadır. Kent kimliğinin

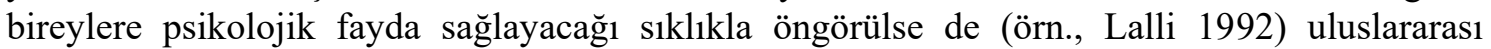
yazında kent kimliği ve öznel iyi oluş arasındaki ilişkiyi inceleyen araştırmaların sayısı sınırlıdır (bk. Long et al. 2003, 20). Bilindiği kadarıyla, Türkiye'de bu konuda daha önce bir araştırma yürütülmemiştir. Çalışmanın, ayrıca, sınırlı sayıda da olsa ülkemizde gerçekleştirilen ve doğayla temas ya da doğal unsurlara maruz kalma ile psikolojik sağlık arasındaki pozitif ilişkiyi odağına alan çalışmalara katkı sağladığı düşünülmektedir (örn., Özdemir \& Semin-Fenkçi 2016, 3027).

Araştırmanın önemli bir sınırlılı̆̆1, ilişkisel araştırma desenine sahip olmasıdır. Bu yüzden, nedensellik ilişkisi kurmak mümkün değildir. Ancak bu çalışmadan elde edilen bulgular, bireylerin yaşadıkları kente ilişkin güçlü bir kimliğe sahip olmalarının olumlu psikolojik çıtıları olduğuna işaret etmektedir. Araştırmanın diğer bir sınırlılığı kesitsel olmasıdır. Bireylerin kent kimliği süreçlerinin uzun vadede sonuçlarını görmek için boylamsal çalışmalara ihtiyaç vardır. Biyofili Hipotezi'ni (Kellert \& Wilson 1995) ve Stres Azaltma Teorisi'ni (Ulrich 1979) doğrular bir biçimde, doğayla temasın bireylerin pozitif duygulanımını artırmakta olduğu göz önünde bulundurulursa, doğanın bireylerin gündelik hayatla başetmelerinde önemli bir kaynak sunduğu söylenebilir. Öte yandan, bu ilişkinin altında yatan sürecin daha iyi anlaşılabilmesi için hem boylamsal hem de deneysel çalışmalara ihtiyaç bulunmaktadır.

Günümüzde nüfusun önemli bir kısmı kentlerde yaşamayı tercih etmektedir. 1927 yılında Türkiye nüfusunun \%75.8'i kırsal alanda yaşamayı tercih etmekte iken (İç Göç İstatistikleri 15.02.2019), bu oran, 2015 itibariyle yalnızca \%7.9'dur (TÜIK 2016, 7-9). Bu duruma insanın doğayla olan bağının önemine işaret eden kavrayışlar (örn., Kaplan 1995; Kellert \& Wilson 1995) 1şığında bakıldığında, doğal alanlardan giderek uzaklaşan kent insanının psikolojik sağlığını sürdürmesinde hangi etmenlerin rol oynadığını anlamak önemli görünmektedir. Araştırmacılara göre (örn., Diener 1984), psikolojik sağlığın en önemli göstergelerinden biri öznel iyi oluştur. $\mathrm{Bu}$ araştırmanın bulgularına bakıldığında, bireylerin psikolojik sağlıklarını kısmen yaşadıkları kentlerle özdeşim sağlayarak ve kentlerin sağladığı ya da kent dışı doğal alanlarda aktivitelerde bulunarak korudukları söylenebilir.

$\mathrm{Bu}$ bulgular, kentte yaşayan insanların psikolojik sağlıklarını sürdürmelerinde rol oynayan çeşitli etmenlere ilişkin araştırmacılara, uygulayıcılara ve yöneticilere fikir verebilir. Bu bağlamda, araştırmacılar kent kimliğinin güçlendirilmesinde rol oynayabilecek etmenleri belirlemeli ve uygulamada bu unsurların nasıl kullanılabileceği tespit edilmelidir. Ayrıca, kent sakinlerinin doğayla temasını artırmak, örneğin konut koşulları uygun olmayan kent sakinlerinin faydalanabileceği hobi bahçeleri sağlamak, doğa sporlarına katılımı teşvik etmek ve bu yönde olanakları genişletmek, kent merkezlerinde kent sakinlerinin kolayca ulaşabileceği yeşil alanların sayısını artırmak gibi girişimler de fayda sağlayabilir.

\section{Yazarın Notu}

Bu çalışma, 2-5 Temmuz 2019 tarihlerinde Moskova'da gerçekleştirilen 16. Avrupa Psikoloji Kongresi'nde sözlü bildiri olarak sunulmuştur.

Mali Destek Bildirimi (Funding)

Çalışma bir kurumdan mali destek almamıştır. 


\section{KAYNAKÇA}

Belanche D., Casaló L.V. \& Flavián C. (2007). "Understanding the Cognitive, Affective and Evaluative Components of Social Urban Identity: Determinants, Measurement, and Practical Consequences". Journal of Environmental Psychology 50 (2007) 138-153.

Bolam B., Murphy S. \& Gleeson K. (2006). "Place-identity and Geographical Inequalities in Health: A Qualitative Study". Psychology and Health 21 (2006) 399-420.

Bonnes M., Scopelliti M., Fornara F. \& Carrus G. (2012). "Urban Environmental Quality". Ed. L. Steg, A. E. van den Berg \& J. I. M. de Groot, Environmental Psychology: An Introduction (2012) 97-106. Oxford.

Brown B. B. \& Perkins D. D. (1992). "Disruptions in Place Attachment". Eds. I. Altman \& S. M. Low. Place Attachment (1992) 279-304. New York.

Cuba L. \& Hummon D. M. (1993). "A Place to Call Home: Identification with Dwelling, Community and Region". The Sociological Quarterly 34 (1993) 111-131.

Diener E. (1984). "Subjective Well-being”. Psychological Bulletin 95 (1984) 542-575.

Diener E., Emmons R. A., Larsen R. J. \& Griffin S. (1985). "The Satisfaction with Life Scale". Journal of Personality Assessment 49 (1985) 71-75.

Diener E., Suh E. M., Lucas R. E. \& Smith H. L. (1999). "Subjective Well-Being: Three Decades of Progress". Psychological Bulletin 125 (1999) 276-302.

Fernández-Portero C., Alarcón D. \& Barrios Á. (2017). "Dwelling Conditions and Life Satisfaction of Older People Through Residential Satisfaction". Journal of Environmental Psychology 49 (2017) 1-7.

Gençöz T. (2000). "Positive and Negative Affect Schedule: A Study of Validity and Reliability". Turkish Journal of Psychology 15 (2000) 27-28.

Hartig T., Evans G. W., Jamner L. D., Davis D. S. \& Gärling T. (2003). "Tracking Restoration in Natural and Urban Field Settings". Journal of Environmental Psychology 23/2 (2003) 109-123.

Hernandez B., Hidalgo M. C., Salazar-Laplace M. E. \& Hess S. (2007). "Place Attachment and Place Identity in Natives and Non-natives". Journal of Environmental Psychology 27 (2007) 310-319.

Herzog T. R. \& Strevey S. J. (2008). "Contact with Nature, Sense of Humor, and Psychological Well-Being". Environment and Behavior 40/6 (2008) 747-776.

İmamoğlu E. O. (2004). Self-construal Correlates of Well-being. Yayımlanmamış veri.

“İç Göç İstatistikleri”. (n.d.). In Türkiye İstatistik Kurumu [TUIK]. 15 Şubat 2019 tarihinde şu kaynaktan alınmıştır: http://tuik.gov.tr/PreTablo.do?alt_id=1067

Jorgensen B. S. \& Stedman R. C. (2001). "Sense of a Place as an Attitude: Lakeshore Owners' Attitudes toward their Properties". Journal of Environmental Psychology 21 (2001) 233248.

Kaplan S. (1995). "The Restorative Benefits of Nature: Toward an Integrative Framework". Journal of Environmental Psychology 15/3 (1995) 169-182.

Karakuş P. (2014). Farklı Kimlik Gruplarında Yer Kimliği, Yerin Anlamlarl ve Kültürlenme Süreçleri. Yayımlanmamış Doktora Tezi. Ege Üniversitesi, İzmir 2014.

Kellert S. R. \& Wilson E. O. (1993). The Biophilia Hypothesis. Washington 1993.

Kemper C. J., Beierlein C., Bensch D., Kovaleva A. \& Rammstedt B. (2012). "Eine Kurzskala zur Erfassung des Gamma-Faktors Sozial Erwünschten Antwortverhaltens: Die Kurzskala Soziale Erwünschtheit-Gamma (KSE-G) [A short scale measurement of the gamma factor 
of socially desirable answering behavior]". GESIS Working Papers 25 (2012).

Kiral-Ucar G., Celik B., Baier M., Müller M. \& Kals E. (2016). "The Ecological Belief in a Just World and Environmental Behavior". Poster Presentation. $31^{\text {st }}$ International Congress of Psychology (24-29 July 2016). (2016). Yokohama, Japan (Abstract published in International Journal of Psychology, 51, 567).

Knez I., Butler A., Ode-Sang Å, Sarlöv-Herlin I. \& Åkerskog A. (2018). "Before and After a Natural Disaster: Disruption in Emotion Component of Place-Identity and Well-Being". Journal of Environmental Psychology 55 (2018) 11-17.

Korpela K. M., Hartig T., Kaiser F. G. \& Fuhrer U. (2001). "Restorative Experience and SelfRegulation in Favorite Places". Environment and Behavior 33/4 (2001) 572-589.

Lalli M. (1992). "Urban-related Identity: Theory, Measurement and Emprical Findings". Journal of Environmental Psychology 12 (1992) 285-303.

Long D. A., Perkins D. D. \& Taylor R. B. (2003). "Self-Identity, Place, and Well-Being: An Ecological Analysis of Neighborhood Place Identity and Social Identity on Psychological Well-Being Controlling for Social Capital, Crime Rates, Defensible Space, Stress, Social Support, and Multilevel Sociodemographics". Oral Presentation. 53 ${ }^{\text {rd }}$ Annual Conference of the Society for the Study of Social Problems (15 August 2003). (2003). Atlanta, USA.

Low S. \& Altman I. (1992). "Place Attachment: A Conceptual Inquiry". Eds. I. Althman \& S. Low, Place Attachment (1992) 1-12. New York.

McMahan E. A. \& Estes D. (2015) "The Effect of Contact with Natural Environments on Positive and Negative Affect: A Meta-Analysis". The Journal of Positive Psychology 10/6 (2015) 507-519.

Nisbet E. K. \& Zelenski J. M. (2011). "Underestimating Nearby Nature: Affective Forecasting Errors Obscure the Happy Path to Sustainability". Psychological Science 22/9 (2011) 11011106.

Özdemir A. \& Semin-Fenkçi M. (2016). "The Role of Aural and Visual Landscape Perception in Patient Psychology". Journal of Human Sciences 13/2 (2016) 3022-3032.

Proshansky H. M. (1978). "The City and Self-Identity". Environment and Behavior 10 (1978) 147-69.

Proshansky H. M., Fabian A. K. \& Kaminoff R. (1983). "Place-Identity: Physical World Socialization of the Self". Journal of Environmental Psychology 3/1 (1983) 57-83.

Tesch-Römer C., Motel-Klingebiel A. \& Tomasik M. J. (2008). Gender Differences in Subjective Well-Being: Comparing Societies with Respect to Gender Equality. Social Indicators Research 85/2 (2008) 329-349.

Türkiye İstatistik Kurumu [TÜİK]. (2016). İstatistiklerle Türkiye 2015. Ankara 2016.

Ulrich R. S. (1979). "Visual Landscapes and Psychological Well-Being". Landscape Research 4 (1979) 17-23.

Ulrich R. S., Simons R. F., Losito B. D., Fiorito E., Miles M. A. \& Zelson M. (1991). "Stress Recovery During Exposure to Natural and Urban Environments". Journal of Environmental Psychology 11 (1991) 201-230.

Van Vugt M., John P., Dowding K. \& Van Dijk, E. (2003). "The Exit of Residential Mobility or the Voice of Political Action? Strategies for Problem Solving in Residential Communities". Journal of Applied Social Psychology 33 (2003) 321-338.

Watson D., Clark L. A. \& Tellegen A. (1988). "Development and Validation of Brief Measures of Positive and Negative Affect: The Panas Scales". Journal of Personality and Social Psychology 54 (1988) 1063-1070. 